\title{
Tetrathiobacter mimigardefordensis sp. nov., isolated from compost, a betaproteobacterium capable of utilizing the organic disulfide 3,3'-dithiodipropionic acid
}

Correspondence

Alexander Steinbüchel steinbu@uni-muenster.de

\author{
Jan Hendrik Wübbeler, ${ }^{1}$ Tina Lütke-Eversloh, ${ }^{1}{ }^{\dagger}$ Stefanie Van Trappen, ${ }^{2}$ \\ Peter Vandamme ${ }^{2}$ and Alexander Steinbüchel ${ }^{1}$
}

\author{
${ }^{1}$ Institut für Molekulare Mikrobiologie und Biotechnologie, Westfälische Wilhelms-Universität \\ Münster, Corrensstraße 3, 48149 Münster, Germany \\ ${ }^{2}$ Laboratory of Microbiology, Department of Biochemistry, Physiology and Microbiology, \\ University of Ghent, K. L. Ledeganckstraat 35, 9000 Ghent, Belgium
}

Polythioesters are bacterial polymers containing sulfur in the backbone and are accumulated as hydrophobic inclusions in the cytoplasm (Lütke-Eversloh \& Steinbüchel, 2004). The first example of this novel type of biopolymer was found to be synthesized by Ralstonia eutropha, a Gramnegative soil bacterium, which naturally accumulates polyhydroxyalkanoates at levels up to more than $90 \%$ of cell dry matter (Pedrós-Alio et al., 1985). R. eutropha can produce various polythioester copolymers under specific cultivation conditions in the presence of 3-mercaptopropionic acid, 3-mercaptovaleric acid, 3,3'-thiodipropionic acid or 3,3' dithiodipropionic acid (DTDP) by employing its polyhydroxyalkanoate synthase (Lütke-Eversloh et al., 2001a, b; Lütke-Eversloh \& Steinbüchel, 2003). Polythioester homopolymers were synthesized from 3-mercaptopropionic acid,

tPresent addresss: Massachusetts Institute of Technology, Department of Chemical Engineering, 77 Massachusetts Avenue 56-422, Cambridge, MA 02139, USA.

Abbreviation: DTDP, 3,3'-dithiodipropionic acid.

The GenBank/EMBL/DDBJ accession number for the 16S rRNA gene sequence of strain DPN7 ${ }^{\top}$ is $A Y 880023$.

A phase-contrast micrograph of cells of strain DPN $7^{\top}$ is available as supplementary material in IJSEM Online. 3-mercaptobutyric acid or 3-mercaptovaleric acid by a recombinant strain of Escherichia coli expressing a nonnatural pathway (Lütke-Eversloh et al., 2002).

R. eutropha and E. coli are unable to utilize these sulfurcontaining substrates as sole carbon sources for growth. In addition, polythioesters currently cannot be synthesized de novo from simple carbon sources and sulphate: their biosynthesis depends on the use of the organic sulfur compounds mentioned above. Little is known (or published) about the catabolic pathways of organic sulfur compounds; exceptions are the catabolism of cysteine and methionine as well that as of dimethylsulfoxide, dimethylsulfoniopropionate and dimethylsulfide as intermediates of the sulfur cycle (Kertesz, 2000; Kiene et al., 2000; Lomans et al., 2002; Yoch, 2002) and the biodesulfurization of benzothiophenes (McFarland, 1999) and of the fluorinated organic sulfur compound bis-(3-pentafluorophenylpropyl)-sulfide (Van Hamme et al., 2004).

To investigate the unknown catabolism of DTDP (Fig. 1), which is one of the precursor substrates currently used for the production of 3-mercaptopropionic acid-containing polythioesters (Lütke-Eversloh \& Steinbüchel, 2003), bacterial 


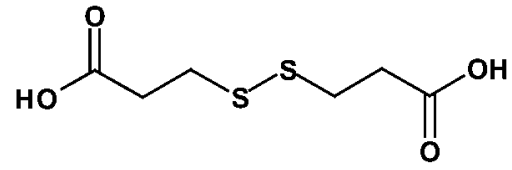

Fig. 1. Structural formula of DTDP.

strains capable of utilizing this organic sulfur compound as a carbon source for growth are desirable for the understanding, and potential application, of DTDP-converting enzymes. In this study, we describe the taxonomic and biochemical characterization of a newly isolated bacterium, strain DPN7 ${ }^{\mathrm{T}}$, which is able to grow with DTDP as the sole carbon source.

Strain DPN7 ${ }^{\mathrm{T}}$ was isolated from matured compost after the sieving process from a compost plant in Münster (Germany) under mesophilic and aerobic conditions. An enrichment culture was prepared by inoculating $50 \mathrm{ml}$ mineral salts medium (MSM) (Schlegel et al., 1961) supplemented with $0.5 \%(\mathrm{w} / \mathrm{v})$ DTDP as the sole carbon source with approximately $2 \mathrm{~g}$ compost. The culture was incubated at $30^{\circ} \mathrm{C}$ for approximately 1 week. Afterwards, serial dilutions of the enrichment culture were spread onto MSM agar plates containing $0.5 \%(\mathrm{w} / \mathrm{v})$ DTDP and then incubated for 7 days at $30^{\circ} \mathrm{C}$. Cells from large colonies were repeatedly transferred to identical agar plates until an axenic culture was obtained. Storage was accomplished in screw-capped vials at $-70{ }^{\circ} \mathrm{C}$ in $20 \%(\mathrm{v} / \mathrm{v})$ glycerol and as lyophilizates.

Colonies of strain $\mathrm{DPN7}^{\mathrm{T}}$ were circular, white to limeyellowish in colour and were more flat than convex. Older colonies on MSM-DTDP agar developed a more yellowish colour. On complex medium, colonies of $\mathrm{DPN}^{\mathrm{T}}$ grew in 1-2 days and appeared more white than yellow in colour. The cells were cultivated at $30^{\circ} \mathrm{C}$ in liquid MSM containing $0.5 \%(\mathrm{w} / \mathrm{v})$ DTDP and samples were withdrawn from different growth stages of the culture. Cells of DPN7 ${ }^{\mathrm{T}}$ were Gram-negative, coccoid rods approximately $1 \cdot 5-2 \mu \mathrm{m}$ in length and $1.5 \mu \mathrm{m}$ in width and often occurred in pairs, as revealed under a Zeiss light microscope (see Supplementary Fig. S1 available in IJSEM Online). Cell motility was observed: after flagella staining performed according to Blenden \& Goldberg (1964), one or two flagella could be detected.

Gram-staining performed according to Gerhardt et al. (1994) gave a negative reaction. Strain DPN $7^{\mathrm{T}}$ was oxidasepositive, as revealed by using Bactident oxidase test strips (Merck), and was catalase-positive, as revealed by adding $3 \%(\mathrm{v} / \mathrm{v}) \mathrm{H}_{2} \mathrm{O}_{2}$ to freshly grown colonies. API $20 \mathrm{NE}$ (bioMérieux) was used to determine the assimilation of some carbon sources and the presence of important enzymes. The utilization of different carbon sources and the growth at different temperatures were investigated in liquid MSM and on MSM agar plates containing $0 \cdot 2 \%$ $(\mathrm{w} / \mathrm{v})$ of the respective carbon source (Table 1$)$, unless
Table 1. Morphological, physiological and biochemical characterization of strain DPN7 ${ }^{\top}$ and Tetrathiobacter kashmirensis LMG $22695^{\top}$

Characteristics were determined either by cultivating the cells at $30{ }^{\circ} \mathrm{C}$ on MSM agar plates containing the respective substrates as sole carbon sources or by using API 20NE tests. ND, Not detected. Cells of both strains are Gram-negative, coccoid rods that produce circular and flat colonies with yellow pigmentation. Both strains can utilize mercaptosuccinic acid, and neither strain can utilize 3,3'-thiodipropionic acid, $4^{\prime}, 4^{\prime}$-dithiodibutyric acid, thioglycolic acid or thiodiglycolic acid. Neither strain can reduce nitrite to dinitrogen gas.

\begin{tabular}{|c|c|c|}
\hline Characteristic & $\begin{array}{l}\text { Strain } \\
\text { DPN7 }^{\mathrm{T}}\end{array}$ & 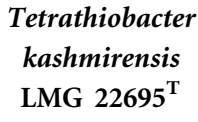 \\
\hline Cell length $(\mu \mathrm{m})$ & $1 \cdot 5-2$ & $1 \cdot 0-1 \cdot 8$ \\
\hline Flagellation & Yes & ND \\
\hline \multicolumn{3}{|l|}{ Utilization of: } \\
\hline D-Fructose & - & + \\
\hline DTDP & + & - \\
\hline 3-Mercaptopropionic acid & $+^{*}$ & - \\
\hline 2-Mercaptopropionic acid & $+^{*}$ & - \\
\hline Dibenzothiophene & + & - \\
\hline Benzothiophene & + & - \\
\hline Reduction of nitrate to nitrite & $-\dagger$ & + \\
\hline
\end{tabular}

${ }^{\star}$ Growth occurred at concentrations of up to $0 \cdot 1 \%(\mathrm{w} / \mathrm{v})$. $\dagger$ Determined using API 20NE tests.

indicated otherwise. Besides having the physiological characteristics shown in Table 1, both strains were positive for utilization of D-glucose, sodium gluconate, acetic acid, propionic acid, butyric acid and succinic acid by conventional cultivation and according to the API 20NE system both strains were positive for utilization of L-arabinose, adipic acid, citric acid and malic acid and negative for D-mannose, D-mannitol, D-maltose, $\mathrm{N}$-acetylglucosamine, capric acid and phenylacetic acid. Additional biochemical characteristics (shown in Table 1) according to the API 20NE system were as follows: both strains were positive for urease activity and negative with regard to the fermentative degradation of glucose, indole production and activity of arginine dihydrolase, $\beta$-glucosidase, protease and $\beta$-galactosidase. This strain had no specific requirement for vitamins and also showed no enhanced growth in the presence of vitamin solution (Mohn, 1995) in defined medium. Growth was typically observed after 2-4 days on MSM agar plates containing $0.5 \%(\mathrm{w} / \mathrm{v})$ DTDP when incubated at $20-37^{\circ} \mathrm{C}$. In liquid MSM containing $0 \cdot 2-0 \cdot 5 \%(w / v)$ DTDP as the sole carbon source, strain DPN7 ${ }^{\mathrm{T}}$ exhibited a characteristic lag phase of approximately $48 \mathrm{~h}$. After that period of time, the exponential phase followed, with a reproducible duration of more than $50 \mathrm{~h}$. To the best of our knowledge, this is the first bacterial isolate found to utilize DTDP as the sole carbon and energy source for growth. Whereas good growth 
occurred with DTDP, no growth was observed with the $\mathrm{C}_{4}$ analogue $4,4^{\prime}$-dithiodibutyric acid or with $3,3^{\prime}$-thiodipropionic acid. The putative cleavage product of DTDP, 3-mercaptopropionic acid, could be utilized only at concentrations of less than $0 \cdot 2 \%$, because of its toxicity (Table 1 ).

The polyester content of the cells, and its composition, was determined upon methanolysis of 7-10 mg lyophilized cells in the presence of $15 \%$ sulfuric acid by gas chromatographic analysis of the resulting methyl esters, as described previously (Brandl et al., 1988; Timm et al., 1990). The cells were capable of synthesizing poly(3-hydroxybutyrate) as a storage compound when they were cultivated in MSM containing gluconate as the sole carbon source. When DTDP or 3-mercaptopropionic acid was provided as an additional carbon source, the cells accumulated a copolymer (up to $20 \mathrm{~mol} \%$ ), consisting of 3-hydroxybutyrate and 3 -mercaptopropionic acid.

Antibiotic-susceptibility testing on nutrient broth agar (Sambrook et al., 1989) containing different concentrations of antibiotics showed good growth of strain $\mathrm{DPN}^{\mathrm{T}}$ on plates containing $5 \mu \mathrm{g}$ chloramphenicol $\mathrm{ml}^{-1}$ and poor growth with $50 \mu \mathrm{g}$ chloramphenicol ml ${ }^{-1}$, but no growth with $500 \mu \mathrm{g}$ chloramphenicol ml ${ }^{-1}$. Growth also occurred in the presence of $50 \mu \mathrm{g}$ thiostrepton $\mathrm{ml}^{-1}$. The strain showed no growth on plates containing $5 \mu \mathrm{g}$ kanamycin $\mathrm{ml}^{-1}, 5 \mu \mathrm{g}$ gentamicin $\mathrm{ml}^{-1}, 6 \cdot 25 \mu \mathrm{g}$ tetracycline $\mathrm{ml}^{-1}$ or $50 \mu \mathrm{g}$ streptomycin $\mathrm{ml}^{-1}$ (the lowest concentrations tested). Strain DPN7 ${ }^{\mathrm{T}}$ was able to grow slowly on agar plates containing ampicillin at concentrations up to the standard concentration for E. coli $\left(75 \mu \mathrm{g} \mathrm{ml}^{-1}\right)$.

To determine the sequence of the 16S rRNA gene, genomic DNA was extracted according to Marmur (1961). The gene was amplified by a PCR using Pfx DNA polymerase (MBI Fermentas) and total genomic DNA as template for the oligonucleotide primers $27 \mathrm{f}$ and $1525 \mathrm{r}$, which were complementary to conserved regions of the $16 \mathrm{~S}$ rRNA gene sequence of $E$. coli. The $1502 \mathrm{bp}$ PCR product was purified using the NucleoTrap kit (Macherey-Nagel) and then sequenced. The PCR product was also ligated to EcoRVlinearized pBluescript II SK(-) (Stratagene) DNA and transformed into competent cells of E. coli TOP10. Plasmid DNA was isolated as described by Birnboim \& Doly (1979).

DNA sequencing was performed by applying the SequiTherm long-read cycle sequencing kit (Epicenter Technologies), with the following oligonucleotides as sequencing primers: $27 \mathrm{f}$ (5'-GAGTTTGATCCTGGCTCAG-3'), 343r (5' -CTGCTGCCTCCCGTA-3'), 357f ( $5^{\prime}$-TACGGGAGGCAGCAG-3'), 519r [5'-G(T/A)-ATTACCGCGGC(T/G)GCTG-3'], 536f [5'-CAGC(C/A)GCCGCGGTAAT(T/A)C-3'], 803f (5'-ATTAGATACCCTGGTAG-3'), 907r (5'-CCGTCAATTCATTTGAGTTT-3'), 1114f (5' -GCAACGAGCGCAACCC-3'), 1385r [5'-CGGTGTGT(A/G)CAAGGCCC-3'] and $1525 \mathrm{r}\left(5^{\prime}\right.$-AGAAAGGAGGTGATCCAGCC- $\left.3^{\prime}\right)$, as well as the universal primer $5^{\prime}$-GTAAAACGACGGCCAGT-3' and the reverse primer $5^{\prime}$-CAGGAAACAGCTATGAC- ${ }^{\prime}$ that hybridize to pBluescript II SK(-). Sequence reactions were accomplished by using the GeneReadIR 4200 DNA analyser (LI-COR). 16S rRNA gene sequences were analysed using the program BLAST (National Center for Biotechnology Information; http://www.ncbi.nlm.nih.gov) by running the BLASTN program. The nucleotide sequence of the 16S rRNA gene of strain $\mathrm{DPN}^{\mathrm{T}}$ and of related type strains belonging to the same phylogenetic group and also to well-known representatives of the Betaproteobacteria were aligned using CLUSTAL X (Thompson et al., 1997). 16S rRNA gene sequences were retrieved from the EMBL database and from the Ribosomal Database Project (Maidak et al., 1997). The resulting trees, displayed with TreeView (Page, 1996), were calculated by using the neighbour-joining method (Saitou \& Nei, 1987).

The nucleotide sequence of the 16S rRNA gene of strain $\mathrm{DPN}^{\mathrm{T}}$ shows high levels of sequence similarity $(98 \cdot 6-$ 98.0\%) to several Alcaligenes sp. strains (Hiraishi et al., 2003; Boivin-Jahns et al., 1996), but these strains could not be analysed further since they are no longer available ( $R$. Christen, personal communication). A sequence similarity of $98.5 \%$ with respect to the type strain of the recently isolated and classified species Tetrathiobacter kashmirensis (Ghosh et al., 2005) was found, whereas lower similarity values were found with respect to the type strains of Castellaniella defragrans (strain $\left.54 \mathrm{Pin}^{\mathrm{T}}\right)(95 \cdot 1 \%)$, Alcaligenes faecalis (the type species of the genus Alcaligenes) (94.0\%), Alcaligenes latus $(88.9 \%)$ and Taylorella equigenitalis $(94 \cdot 7 \%)$. The phylogenetic position of strain $\mathrm{DPN}^{\mathrm{T}}$ is illustrated in a neighbour-joining dendrogram with Burkholderia kururiensis as the outgroup (Fig. 2).

For determination of the $\mathrm{G}+\mathrm{C}$ content, DNA was enzymically degraded into nucleosides, as described by Mesbah et al. (1989), which were then separated by HPLC using a Waters Symmetry Shield C8 column thermostatted at $37^{\circ} \mathrm{C}$. The solvent used was $0.02 \mathrm{M} \mathrm{NH}_{4} \mathrm{H}_{2} \mathrm{PO}_{4}(\mathrm{pH} 4 \cdot 0)$ with $1.5 \%$ acetonitrile. Non-methylated $\lambda$ phage DNA (Sigma) was used as the calibration reference. The DNA $\mathrm{G}+\mathrm{C}$ content of strain $\mathrm{DPN7}^{\mathrm{T}}$ was $55 \cdot 1 \mathrm{~mol} \%$, which is the same as that reported for Tetrathiobacter kashmirensis LMG $22695^{\mathrm{T}}$. The separated phylogenetic position of strain $\mathrm{DPN}^{\mathrm{T}}$ was confirmed by DNA-DNA hybridization. Experiments were performed at $42{ }^{\circ} \mathrm{C}$ with photobiotinlabelled probes in microplate wells as described previously (Goris et al., 1998), using an HTS7000 Bio Assay Reader (PE Applied Biosystems) for the fluorescence measurements. The value for DNA-DNA hybridization to Tetrathiobacter kashmirensis LMG 22696 was only $41 \cdot 4 \%$, whereas the values obtained with A. faecalis subsp. faecalis LMG $1229^{\mathrm{T}}$ and with C. defragrans LMG $18538^{\mathrm{T}}$ were low (7 and $5 \%$, respectively).

Agarose gel electrophoresis of crude extracts of cells of strain $\mathrm{DPN}^{\mathrm{T}}$ obtained by the method of Birnboim \& Doly (1979) revealed the presence of a $22 \mathrm{kbp}$ plasmid. In preliminary experiments, this plasmid could not be connected with the capacity to utilize DTDP or other organic sulfur 


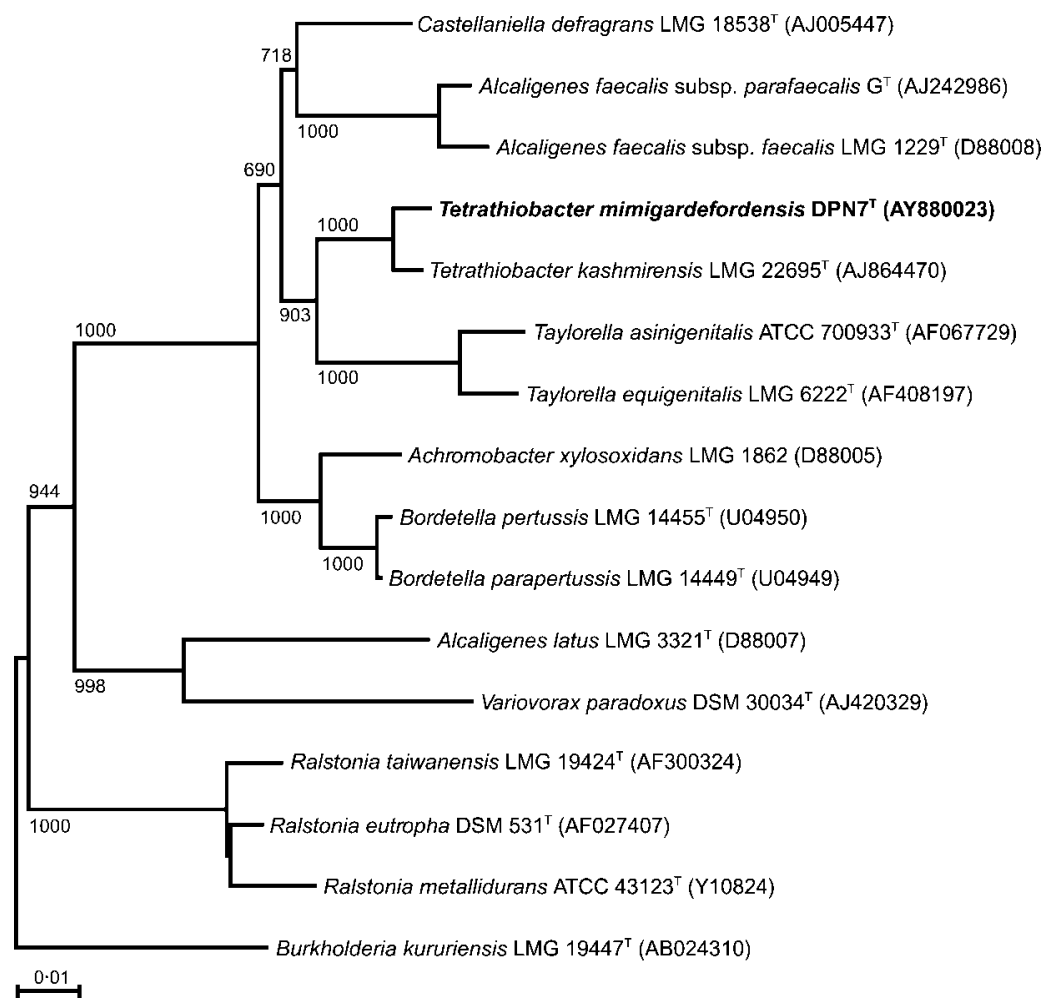

Fig. 2. Phylogenetic tree, based on $16 \mathrm{~S}$ rRNA gene sequences, showing the position of strain DPN7 ${ }^{\top}$ within the Betaproteobacteria; Burkholderia kururiensis LMG $19447^{\top}$ was used as the outgroup. Bootstrap values exceeding $60 \%$ are shown at branch points. Accession numbers are given in parentheses. Bar, 0.01 substitutions per nucleotide position.

compounds. No plasmids were detected in Tetrathiobacter kashmirensis LMG $22695^{\mathrm{T}}$ or Tetrathiobacter kashmirensis LMG 22696.

Fatty acid analysis was carried out with a loopful of well-grown cells after an incubation period of $48 \mathrm{~h}$. Fatty acid methyl esters were prepared, separated and identified using the Microbial Identification System (Microbial ID) as described previously (Vandamme et al., 1992). Strain $\mathrm{DPN7}^{\mathrm{T}}$ contained the following fatty acid components: $12: 0(4 \cdot 5 \%), 16: 0(18 \cdot 2 \%), 17: 0$ cyclo $(4 \cdot 8 \%), 16: 03-$ $\mathrm{OH}(3 \cdot 3 \%), 18: 1 \omega 7 c(26 \cdot 5 \%), 18: 0(2 \cdot 1 \%), 19: 0 \omega 8 c$ cyclo $(2 \cdot 6 \%)$, summed feature $2(13 \cdot 3 \%$, comprising $12: 0$ ALDE, 16:1 iso I and/or 14:0 3-OH) and summed feature $3(23.3 \%$, comprising $16: 1 \omega 7 c$ and/or iso- $15: 02-\mathrm{OH})$ (summed features are groups of two or three fatty acids that cannot be distinguished using the Microbial Identification System). Members of this phylogenetic lineage typically contain $14: 03-\mathrm{OH}$ and $16: 1 \omega 7 c$; therefore, the peaks designated as summed features 2 and 3 probably corresponded to these fatty acids. A comparison with the fatty acid profile of Tetrathiobacter kashmirensis LMG $22695^{\mathrm{T}}$ (data available in Ghosh et al., 2005) revealed only small variations in composition.

The whole-cell protein profile of strain $\mathrm{DPN}^{\mathrm{T}}$ was determined by using SDS-PAGE (Pot et al., 1994) and was compared with those of reference taxa belonging to this bacterial lineage. Data for reference strains were taken from previous studies (Coenye et al., 2003; Jang et al., 2001). The protein profile of strain DPN7 ${ }^{\mathrm{T}}$ was clearly different from those of Alcaligenes, Achromobacter, Bordetella, Castellaniella and Taylorella reference strains, as well as from the type species of the genus Tetrathiobacter (Fig. 3).

The phylogenetic classification of strain $\mathrm{DPN} 7^{\mathrm{T}}$ resulted largely from the analysis of sequence similarities of the $16 \mathrm{~S}$ rRNA gene. The similarity values with respect to the taxonomically closest type strains were about $95 \%$ or less, with the exception of that for Tetrathiobacter kashmirensis LMG $22695^{\mathrm{T}}(98 \cdot 5 \%)$. Both the colony morphology and the cell morphology of these two strains on MSM, MSTY (Mukhopadhyaya et al., 2000) and complex media appeared to be identical. In addition, the DNA G $+\mathrm{C}$ contents of the two strains were the same $(55 \cdot 1 \mathrm{~mol} \%)$, but the DNA-DNA hybridization value was relatively low (only $41 \cdot 4 \%$ ); much lower values ( 7 and $5 \%$, respectively) were obtained with $A$. faecalis subsp. faecalis LMG $1229^{\mathrm{T}}$ and C. defragrans $\mathrm{LMG}$ $18538^{\mathrm{T}}$. Furthermore, the physiological and biochemical characteristics of strain DPN7 ${ }^{\mathrm{T}}$ (Table 1), particularly with regard to utilization of the organic disulfide DTDP, led to the phylogenetic differentiation of strain $\mathrm{DPN}^{\mathrm{T}}$ and Tetrathiobacter kashmirensis. Therefore, strain $\mathrm{DPN}^{\mathrm{T}}$ should be classified as the type strain of a novel species of the genus Tetrathiobacter, for which the name Tetrathiobacter mimigardefordensis sp. nov. is proposed.

\section{Description of Tetrathiobacter mimigardefordensis sp. nov.}

Tetrathiobacter mimigardefordensis (mi.mi.gar.de.for.den'sis. M.L. masc. adj. mimigardefordensis of Mimegardefordum, 


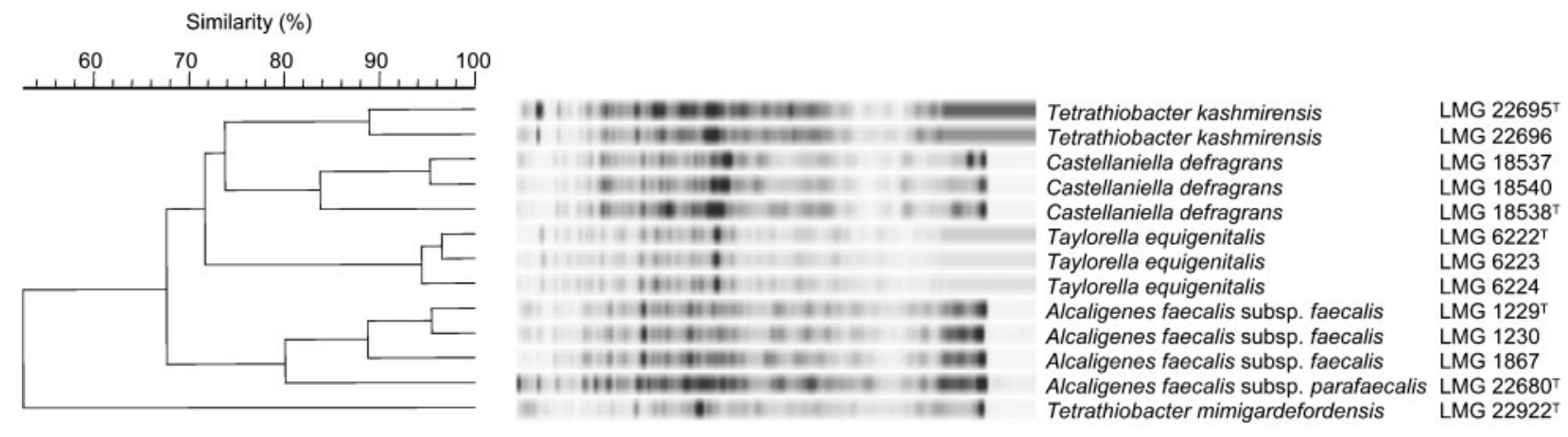

Fig. 3. Digitized representation of normalized whole-cell protein profile of strain DPN7 ${ }^{\top}$ compared with the whole-cell protein profiles of reference strains. The dendrogram was derived from unweighted pair group average linkage of correlation coefficients between the protein patterns of the strains studied. The correlation coefficient, $r$, is expressed as percentage similarity for convenience.

a medieval name of Münster, where the type strain was isolated).

Cells are motile, Gram-negative, non-spore-forming coccoid rods (approx. 1.5-2 $\mu \mathrm{m}$ in length). They are oxidaseand catalase-positive, showing an oxidative metabolism. The temperature range for growth is $15-40{ }^{\circ} \mathrm{C}$ and the best growth occurs at $30-37^{\circ} \mathrm{C}$. Colonies on DTDP-containing agar plates are more flat than convex, up to $3 \mathrm{~mm}$ in diameter and white to lime-yellowish in colour, showing an increase in yellow colour with culture age. On complex medium, colonies grow in 1-2 days and appear more white than yellow and are up to $5 \mathrm{~mm}$ in diameter. Susceptible to kanamycin, gentamicin, tetracycline and streptomycin, with no significant antibiotic resistance. Fatty acid profile largely comprises $18: 1 \omega 7 c(26 \cdot 5 \%), 16: 0(18 \cdot 2 \%)$ and of the two fatty acids $16: 1 \omega 7 c$ and/or iso-15:02-OH (together constituting $23.3 \%$ ), which cannot be distinguished using the Microbial Identification System. The DNA G+C content of the type strain is $55 \cdot 1 \mathrm{~mol} \%$. Carbon sources utilized are indicated in Table 1.

The type strain, $\mathrm{DPN7}^{\mathrm{T}}\left(=\mathrm{DSM} 17166^{\mathrm{T}}=\mathrm{LMG} 22922^{\mathrm{T}}\right)$, was isolated from a sample of matured compost from the compost plant in Münster (Germany).

\section{Acknowledgements}

P. V. is indebted to the Fund for Scientific Research - Flanders (Belgium) for research grants.

\section{References}

Birnboim, H. C. \& Doly, J. (1979). A rapid alkaline extraction procedure for screening recombinant plasmid DNA. Nucleic Acids Res 7, 1513-1523.

Blenden, D. C. \& Goldberg, H. S. (1964). Silver impregnation stain for Leptospira and Flagella. J Bacteriol 89, 899-900.
Boivin-Jahns, V., Ruimy, R., Bianchi, A., Daumas, S. \& Christen, R. (1996). Bacterial diversity in a deep-subsurface clay environment. Appl Environ Microbiol 62, 3405-3412.

Brandl, H., Gross, A., Lenz, R. W. \& Fuller, R. C. (1988). Pseudomonas oleovorans as a source of poly( $\beta$-hydroxyalkanoates) for potential applications as biodegradable polyesters. Appl Environ Microbiol 54, 1977-1982.

Coenye, T., Vancanneyt, M., Falsen, E., Swings, J. \& Vandamme, P. (2003). Achromobacter insolitus sp. nov. and Achromobacter spanius sp. nov., from human clinical samples. Int J Syst Evol Microbiol 53, 1819-1824.

Gerhardt, P., Murray, R. G. E., Wood, W. A. \& Krieg, N. R. (editors) (1994). Methods for General and Molecular Bacteriology. Washington, DC: American Society for Microbiology.

Ghosh, W., Bagchi, A., Manda, S., Dam, B. \& Roy, P. (2005). Tetrathiobacter kashmirensis gen. nov., sp. nov., a novel mesophilic, neutrophilic, tetrathionate-oxidizing, facultatively chemolithotrophic betaproteobacterium isolated from soil from a temperate orchard in Jammu and Kashmir, India. Int J Syst Evol Microbiol 55, 1779-1787.

Goris, J., Suzuki, K., De Vos, P., Nakase, T. \& Kersters, K. (1998). Evaluation of a microplate DNA-DNA hybridization method compared with the initial renaturation method. Can J Microbiol 44, 1148-1153.

Hiraishi, A., Narihiro, T. \& Yamanaka, Y. (2003). Microbial community dynamics during start-up operation of flowerpot-using fed-batch reactors for composting of household biowaste. Environ Microbiol 5, 765-776.

Jang, S. S., Donahue, J. M., Arata, A. B., Goris, J., Hansen, L. M., Earley, D. L., Vandamme, P. A. R., Timoney, P. J. \& Hirsh, D. C. (2001). Taylorella asinigenitalis sp. nov., a bacterium isolated from the genital tract of male donkeys (Equus asinus). Int J Syst Evol Microbiol 51, 971-976.

Kertesz, M. A. (2000). Riding the sulfur cycle - metabolism of sulfonates and sulfate esters in Gram-negative bacteria. FEMS Microbiol Rev 24, 135-175.

Kiene, R. P., Linn, L. J. \& Bruton, J. A. (2000). New and important roles for DMSP in marine microbial communities. J Sea Res 43, 209-224.

Lomans, B. P., van der Drift, C., Pol, A. \& Op den Camp, H. J. M. (2002). Microbial cycling of volatile organic sulfur compounds. Cell Mol Life Sci 59, 575-588. 
Lütke-Eversloh, T. \& Steinbüchel, A. (2003). Novel precursor substrates for polythioesters (PTE) and limits of PTE biosynthesis in Ralstonia eutropha. FEMS Microbiol Lett 221, 191-196.

Lütke-Eversloh, T. \& Steinbüchel, A. (2004). Microbial polythioesters. Macromol Biosci 4, 165-174.

Lütke-Eversloh, T., Bergander, K., Luftmann, H. \& Steinbüchel, A. (2001a). Identification of a new class of biopolymer: bacterial synthesis of sulfur-containing polymer with thioester linkages. Microbiology 147, 11-19.

Lütke-Eversloh, T., Bergander, K., Luftmann, H. \& Steinbüchel, A. (2001b). Biosynthesis of poly(3-hydroxybutyrate-co-3-mercaptobutyrate) as a sulfur analogue to poly(3-hydroxybutyrate) (PHB). Biomacromolecules 2, 1061-1065.

Lütke-Eversloh, T., Fischer, A., Remminghorst, U., \& 8 other authors (2002). Biosynthesis of novel thermoplastic polythioesters by engineered Escherichia coli. Nat Mater 1, 236-240.

Maidak, B. L., Olsen, G. J., Larsen, N., Overbeek, R., McCaughey, M. J. \& Woese, C. R. (1997). The RDP (Ribosomal Database Project). Nucleic Acids Res 25, 109-111.

Marmur, J. (1961). A procedure for the isolation of desoxyribonucleic acid from microorganisms. J Mol Biol 1, 208-218.

McFarland, B. L. (1999). Biodesulfurization. Curr Opin Microbiol 2, 257-264.

Mesbah, M., Premachandran, U. \& Whitman, W. B. (1989). Precise measurement of the $\mathrm{G}+\mathrm{C}$ content of deoxyribonucleic acid by highperformance liquid chromatography. Int J Syst Bacteriol 39, 159-167.

Mohn, W. W. (1995). Bacteria obtained from a sequencing batch reactor that are capable of growth on dehydroabietic acid. Appl Environ Microbiol 61, 2145-2150.

Mukhopadhyaya, P. N., Deb, C., Lahiri, C. \& Roy, P. (2000). A soxA gene, encoding a diheme cytochrome $c$, and sox locus, essential for sulfur oxidation in a new sulfur lithotrophic bacterium. J Bacteriol 182, 4278-4287.

Page, R. D. M. (1996). TreeView: an application to display phylogenetic trees on personal computers. Comput Appl Biosci 12, 357-358.
Pedrós-Alio, C., Mas, J. \& Guerrero, R. (1985). The influence of poly- $\beta$-hydroxybutyrate accumulation on cell volume and buoyant density in Alcaligenes eutrophus. Arch Microbiol 143, 178-184.

Pot, B., Vandamme, P. \& Kersters, K. (1994). Analysis of electrophoretic whole-organism protein fingerprints. In Chemical Methods in Prokaryotic Systematics, pp. 493-521. Edited by M. Goodfellow \& A. G. O'Donnell. Chichester: Wiley.

Saitou, N. \& Nei, M. (1987). The neighbor-joining method: a new method for reconstructing phylogenetic trees. Mol Biol Evol 4, 406-425.

Sambrook, J., Fritsch, E. F. \& Maniatis, T. (1989). Molecular Cloning: a Laboratory Manual, 2nd edn. Cold Spring Harbor, NY: Cold Spring Harbor Laboratory.

Schlegel, H. G., Kaltwasser, H. \& Gottschalk, G. (1961). A submersion method for culture of hydrogen-oxidizing bacteria: growth physiological studies. Arch Mikrobiol 38, 209-222 (in German).

Thompson, J. D., Gibson, T. J., Plewniak, F., Jeanmougin, F. \& Higgins, D. G. (1997). The CLUSTAL_X windows interface: flexible strategies for multiple sequence alignment aided by quality analysis tools. Nucleic Acids Res 25, 4876-4882.

Timm, A., Byrom, D. \& Steinbüchel, A. (1990). Formation of blends of various poly(3-hydroxyalkanoic acids) by a recombinant strain of Pseudomonas oleovorans. Appl Microbiol Biotechnol 33, 296-301.

Vandamme, P., Vancanneyt, M., Pot, B. \& 10 other authors (1992). Polyphasic taxonomic study of the emended genus Arcobacter with Arcobacter butzleri comb. nov. and Arcobacter skirrowii sp. nov., an aerotolerant bacterium isolated from veterinary specimens. Int J Syst Bacteriol 42, 344-356.

Van Hamme, J. D., Fedorak, P. M., Foght, J. M., Gray, M. R. \& Dettman, H. D. (2004). Use of a novel fluorinated organosulfur compound to isolate bacteria capable of carbon-sulfur bond cleavage. Appl Environ Microbiol 70, 1487-1493.

Yoch, D. C. (2002). Dimethylsulfoniopropionate: its sources, role in the marine food web, and biological degradation to dimethylsulfide. Appl Environ Microbiol 68, 5804-5815. 